\title{
Autologous tumor lysate-loaded dendritic cell vaccination combined with Sunitinib for metastatic renal cell carcinoma
}

\author{
Kazuhiro Kakimi ${ }^{*}$, Hirokazu Matsushita ${ }^{1}$, Yutaka Enomoto ${ }^{2}$, Tohru Nakagawa ${ }^{3}$, Haruki Kume ${ }^{3}$, Yukio Homma $^{3}$ \\ From Society for Immunotherapy of Cancer 29th Annual Meeting \\ National Harbor, MD, USA. 6-9 November 2014
}

\section{Background}

The antibodies that block immunological checkpoints have been successfully applied for the treatment of cancer. Similar effects are expected by molecular targeted therapy, which primarily aims to inhibit molecular pathways for tumor cell growth and survival. Such small molecular drugs may modulate the immune system, which raises the possibility that targeted therapy might be effectively combined with immunotherapy. Sunitinib, a tyrosine kinase inhibitor currently in use for the treatment of metastatic renal cell carcinoma (mRCC), has been reported to modulate immunosuppressive cells such as myeloid-derived suppressor cells (MDSCs) and regulatory T cells (Tregs). We conducted a clinical study of dendritic cell (DC)-based immunotherapy together with Sunitinib in mRCC patients in an effort to enhance immunotherapeutic efficacy by inhibiting immunosuppressive cells.

\section{Methods}

Patients aged $\geq 20$ years with advanced or recurrent mRCC who underwent nephrectomy were eligible for this study. Autologous tumor samples were obtained by surgery and used for preparing autologous tumor lysate. Leukapheresis was performed to obtain peripheral blood mononuclear cells (PBMCs). DCs were generated from adherent PBMCs in the presence of recombinant human granulocyte macrophage colony-stimulating factor (GM-CSF) $(500 \mathrm{IU} / \mathrm{ml})$ and IL-4 $(500 \mathrm{IU} / \mathrm{ml})$. Mature DCs were loaded with autologous tumor lysate by electroporation. Eight patients were enrolled in the study and received Sunitinib at a dose of $50 \mathrm{mg}$ p.o. daily for 28 days followed by 14 days of rest. Tumor lysate-loaded DCs were

The University of Tokyo Hospital, Tokyo, Japan

Full list of author information is available at the end of the article administered subcutaneously every two weeks, with concomitant Sunitinib.

\section{Results}

No severe adverse events related to vaccination were observed. Sunitinib decreased the frequencies of MDSCs in peripheral blood of 5 patients and of Tregs in 3. Tumor lysate-reactive CD4 or CD8 $\mathrm{T}$ cell responses were observed in 5 patients, 4 of whom showed decreased frequencies of Tregs and/or MDSCs. The remaining 3 patients who failed to develop tumor-reactive $T$ cell responses had high levels of IL-8 in their sera and did not show consistent reductions in MDSCs and Tregs. The antigen spreading was observed; the production of antibodies against several cancer testis antigen was induced after $\mathrm{DC}$ vaccination. The median overall survival was 346 days and median progression-free survival was 164 days. One patient achieved a complete response, another patient had a partial response, 2 had stable disease and 3 had progressive disease according to the RECIST (one N/A).

\section{Conclusions}

DC-based immunotherapy combined with Sunitinib is safe and feasible for patients with mRCC.

\section{Trial registration}

Trial registration number: UMIN000002136

\section{Acknowledgements \\ Collaboration with Medinet Co. Ltd.}

\section{Authors' details}

${ }^{1}$ The University of Tokyo Hospital, Tokyo, Japan. ${ }^{2}$ Mitsui Memorial Hospital, Tokyo, Japan. ${ }^{3}$ The University of Tokyo Hospital, Bunkyo-Ku, Japan. 
doi:10.1186/2051-1426-2-S3-P50

Cite this article as: Kakimi et al: Autologous tumor lysate-loaded

dendritic cell vaccination combined with Sunitinib for metastatic renal

cell carcinoma. Journal for ImmunoTherapy of Cancer 2014 2(Suppl 3):P50

Submit your next manuscript to BioMed Central and take full advantage of:

- Convenient online submission

- Thorough peer review

- No space constraints or color figure charges

- Immediate publication on acceptance

- Inclusion in PubMed, CAS, Scopus and Google Scholar

- Research which is freely available for redistribution 